\title{
Pengaruh inflasi dan jumlah uang beredar terhadap nilai tukar rupiah dengan pendekatan model struktural VAR
}

\author{
Tuty Alawiyah*; Haryadi; Yohannes Vyn Amzar
}

Prodi Ekonomi Pembangunan, Fak. Ekonomi dan Bisnis, Universitas Jambi

*E-mail korespodensi : tuty.alawiyah18@yahoo.com

\begin{abstract}
The purpose of this study are, firstly to analyze exchange rate trends of rupiah, centtral bank policy rates, inflation and money supply in Indonesia from January 2019 to December 2019. Secondly, to analyzes the effect of central bank policy rate, inflation and the money supply to the rupiah exchange rate in January 2013 - Desember 2018. The method used in this research are descriptive and quantitative analysis with trend analysis tools and multiple linier regression VAR models with the Ordinary Least Square $(O L S)$. The results of the study found that, the first trend data from the rupiah exchange rate variable of January 2019 period - December 2019 of IDR 15.145 US\$, the central bank's policy interest rate was 4.5 percent, inflation was 2.15 percent and the money supply was an average of Rp.5.966.9112,17 billion. Secondly, from the processed data it was found that central bank policy rates and the money supply has a positive effect on the rupiah exchange rate of January 2013 period - December 2018. While the inflation variable has a negative impact on the rupiah exchange rate of January 2013 period - December 2018.
\end{abstract}

Keywords : Rupiah exchange rate, Central bank policy interest rate, Money supply

\begin{abstract}
Abstrak
Penelitian ini bertujuan untuk, pertama menganalisis trend nilai tukar rupiah, suku bunga kebijakan bank sentral, inflasi dan jumlah uang beredar di Indonesia periode Januari 2019 - Desember 2019. Kedua menganalisis pengaruh suku bunga kebijakan bank sentral, inflasi dan jumlah uang beredar terhadap nilai tukar rupiah periode Januari 2013 - Desember 2018. Metode yang digunakan dalam penelitian ini adalah analisis deskriptif kuantitatif dengan alat analisis trend dan regresi linier berganda model VAR dengan metode Ordinary Least Square (OLS). Hasil studi menemukan bahwa, pertama trend data dari variabel nilai tukar rupiah selama periode Januari 2019 - Desember 2019 sebesar Rp. 15.145 US\$, suku bunga kebijakan bank sentral sebesar 4.5 persen, inflasi sebesar 2.15 persen dan jumlah uang beredar rata-rata sebesar Rp. 5.966.912,17 millyar. Kedua, dari hasil olahan data ditemukan bahwa suku bunga kebijakan bank sentral, dan jumlah uang beredar berpengaruh positif terhadap nilai tukar rupiah selama periode Januari 2013 - Desember 2018, sedangkan variabel inflasi berpengaruh negatif terhadap nilai tukar rupiah selama periode Januari 2013 - Desember 2018.
\end{abstract}

$\overline{\text { Kata kunci :Nilai tukar rupiah, Suku bunga kebijakan bank sentral, Inflasi, Jumlah }}$ uang beredar

\section{PENDAHULUAN}

Kurs merupakan salah satu variabel yang terpenting, mengingat pengaruhnya yang besar bagi neraca transaksi berjalan maupun bagi variabel-variabel makro ekonomi lainnya (Musyaffa' dan Sri, 2017). Dengan adanya kurs suatu negara dapat bertransaksi ke negara lain dapat kondusif. Namun kendala yang dihadapi dalam nilai 
mata uang ini, bahwa tidak setiap negara memiliki nilai mata uang yang sama. Krisis nilai tukar dapat berdampak buruk untuk ekonomi suatu negara. Krisis nilai tukar tidak hanya mengakibatkan harga-harga melambung tinggi, tetapi juga mengakibatkan kontraksi perekonomian yang cukup dalam (Fauji, 2016).

Sejak Indonesia menganut sistem nilai tukar mengambang bebas, pergerakan nilai tukar rupiah mengalami tekanan yang signifikan dari mata uang negara lain khususnya dari Dollar Amerika Serikat (Marsuki, 2006).Faktor - faktor makro ekonomi yang dapat mempengaruhi nilai tukar terhadap dollar Amerika yaitu inflasi, suku bunga dan jumlah uang beredar. Tingkat inflasi domestik yang lebih tinggi dari luar negeri maka akan lebih menguntungkan untuk mengimpor barang dari luar negeri yang lebih murah (Agustin, 2009).

Perkembangan nilai tukar rupiah terhadap US\$, suku bunga, inflasi, jumlah uang beredar periode Januari 2013 - Oktober 2018. Data nilai tukar terhadap US\$ dari Januari tahun 2013 sampai oktober 2018 mengalamai fluktuatif. Pada tahun 2013 besaran nilai tukar relatif mengalami kenaikan, terdepresiasinya nlai tukar ini dikarenakan berkurangnya arus modal asing ke dalam negeri akibat sentimen global khususnya normalisasi kebijakan moneter bank sentral AS. Begitupun pada sepanjang tahun 2016, besaran nilai tukar berkisar kurang lebih RP. 13.000 US\$. Angka nilai tukar mulai melonjak naik dari tahun ke tahun pada 2017 sampai Desember 2018 hingga mencapai sebesar RP. 14.496 US\$ ini disebabkan oleh meningkatnya ekspektasi kenaikan suku bunga, normalisasi kebijakan moneter serta rencana reformas pajak di AS. Bank Indonesia akan terus menjaga bekerjanya mekanisme pasar. Untuk data suku bunga dan inflasi pada periode Januari 2013 sampai Desember 2018 mengalami fluktuatif, inflasi periode Juni 2017 tercatat $0,13 \%$ dan lebih rendah dibandingkan dengan rata-rata inflasi di bulan Juni tiga tahun terakhir sebesar $0,15 \%$. Terkendalinya inflasi dikarenakan rendahnya harga harga impor dan terbatasnya konsumsi. Bank Indonesia terluas melakukan penargetan inflasi untuk pengendalian inflasi dengan.

Pergerakan nilai tukar yang fluktuatif diatas mempengaruhi mekanisme dan kekuatan pasar internasional. Kondisi ini didukung oleh laju inflasi yang meningkat tajam dan menurunnya kepercayaan masyarakat terhadap perbankan nasional. Suku bunga, inflasi dan nilai tukar sangat berhubungan erat. Dengan merubah tingkat suku bunga, bank sentral suatu negara bisa mempengaruhi inflasi dan nilai tukar mata uang. Suku bunga yang lebih tinggi akan menyebabkan permintaan mata uang negara tersebut meningkat. Investor domestik dan luar negeri akan tertarik dengan return yang lebih besar (Yeniwati, 2014).

\section{METODE}

\section{Jenis dan sumber data}

Jenis data yang digunakan dalam penelitian ini adalah data sekunder jenis time series bulanan periode Januari 2013 - Oktober 2018, Penelitian ini terdiri atas beberapa variabel, yaitu tingkat suku bunga, inflasi dan jumlah uang beredar sebagai variabel bebas (independen) dan nilai tukar rupiah terhadap US dollar sebagai variabel bebas (dependen). Sumber data dalam penelitian ini didapat dari website Bank Indonesia.

\section{Metode pengumpulan data}

Metode pengumpulan data dipakai dalam penelitian ini adalah library research atau studi kepustakaan yaitu berdasarkan data dengan cara mengamati, mencatat, mempelajari, uraian - uraian dari buku, skripsi, artikel, jurnal yang mempunyai relevansi dengan penelitian ini. 


\section{Metode dan alat analisis data}

Metode analisis yang digunakan dalam dalam penelitian ini adalah analisis kuantitatif yang berarti penjelasan dari hasil suatu penelitian dengan menggunakan angka-angka yang diolah terlebih dahulu sesuai dengan permasalahan yang ada. Model analisis yang digunakan dalam penelitian ini adalah Analisis Trend dan Analisis Regresi Model VAR.

\section{Analisis trend}

Analisis trend adalah suatu gerakan (kecendrungan) naik atau turun dalam jangka panjang yang diperoleh dari rata - rata perubahan dari waktu ke waktu, trend juga digunakan untuk meramalkan suatu kejadian yang mungkin terjadi pada masa mendatang. Alat analisis yang digunakan dalam analisis trend ini dengan bantuan aplikasi Microsoft Excel. Rumus yang dapat digunakan dalam analisis ini adalah sebagai berikut :

$\mathbf{Y}=\mathbf{a}+\mathbf{b X}$

Dimana :

$\mathrm{Y}=$ Variabel yang dicari trend nya

$\mathrm{a}=$ Konstanta

$\mathrm{b}=$ Parameter

$\mathrm{X}=$ Periode yang dicari trend nya

\section{Analisis regresi model VAR}

Model Vector Auto Regressive (VAR) merupakan suatu model VAR dibangun untuk mengatasi hal dimana hubungan antarvariabel ekonomi dapat tetap di estimasi tanpa perlu menitikberatkan masalah eksogenitas (Widarjono, 2007). Dalam pendekatan ini semua variabel dianggap sebagai endogen dan estimasi dapat dilakukan secara serentak atau sekuensial. Alat analisis yang digunakan dalam regresi model VAR ini dengan bantuan aplikasi Eviews 9.0. Suatu model VAR sederhana dapat diformulasikan sebagai berikut:

Adapun model VAR dalam penelitian ini adalah :

$\mathrm{NT}_{\mathrm{t}}=\beta_{1,0}+\beta_{1,1} \mathrm{NT}_{1 \mathrm{t}-1}+\beta_{1,2} \mathrm{SB}_{2 \mathrm{t}-2}+\beta_{1,3} \mathrm{INF}_{3 \mathrm{t}-3}+\beta_{1,4} \mathrm{JUB}_{4 \mathrm{t}-3}+u_{1 t}$

Dimana :

$\mathrm{NT}=$ nilai tukar Rupiah/US\$

$\beta=$ konstanta

$\mathrm{SB}=$ suku bunga kebijakan bank sentral

INF = inflasi

JUB $=$ jumlah uang beredar

$u_{1 t}=$ error term

\section{HASIL DAN PEMBAHASAN}

\section{Analisis trend nilai tukar}

Menurut Sukirno (2006), kurs dapat diartikan sebagai jumlah suatu mata uang yang diperlukan untuk membeli satu satuan mata uang lain.Misalnya kurs dollar terhadap rupiah sama dengan jumlah rupiah yang diperlukan untuk membeli satu dollar Amerika Serikat. 


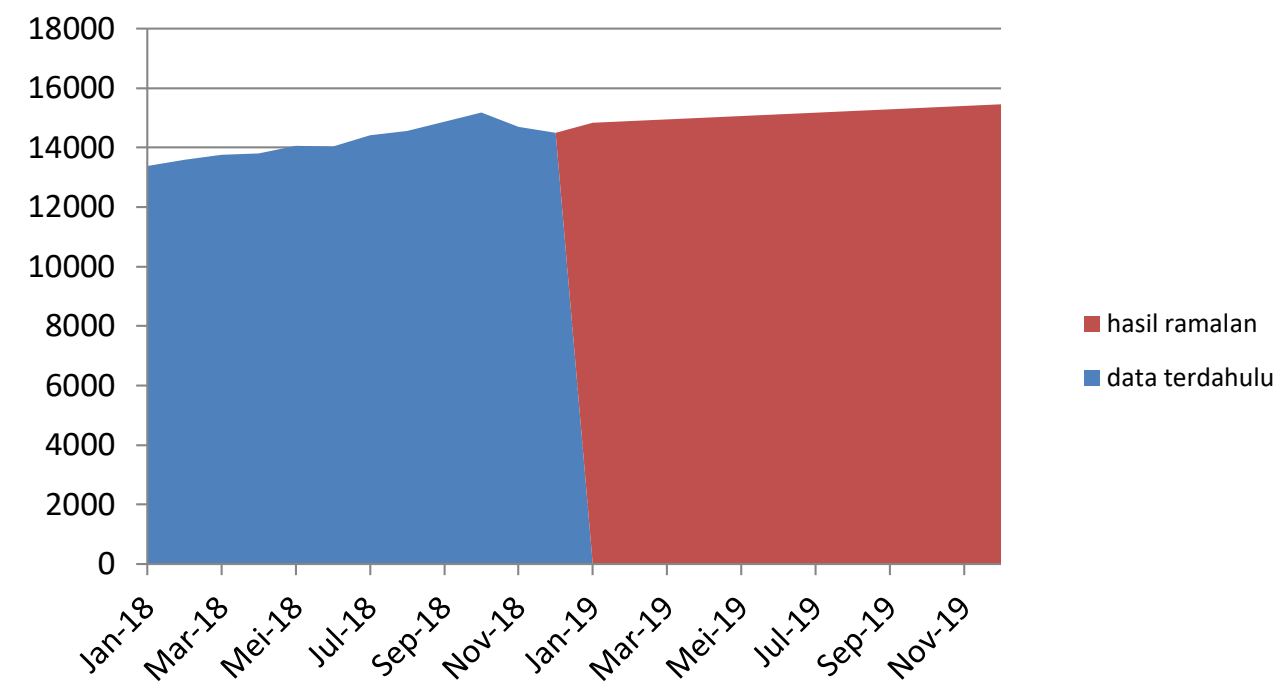

Sumber : Bank Indonesia, data diolah (2019).

Grafik 1. Trend nilai tukar

Berdasarkan Grafik 1 diketahui bahwa trend nilai tukar pada periode Januari Desember 2019 mengalami peningkatan yg signifikan. Di awal periode Januari 2019 angka nilai tukar sebesar Rp. 14834,63 US\$. Periode selanjtnya pada Februari 2019 nilai tukar kembali mengalami peningkatan hingga Rp. 14891,09 US\$, diikuti pada periode Desember 2019 naik kembali hingga mencapai Rp. 15455,68 US\$.

\section{Analisis trend suku bunga kebijakan bank sentral}

Menurut Mankiw (2006), suku bunga adalah harga yang harus dibayar bank atau peminjam lainnya untuk memanfaatkan uang selama jangka waktu tertentu. Suku Bunga merupakan salah satu sasaran kebijakan monter yang sangat besar pengaruhnya karena suku bunga memegang peranan penting didalam kegiatan perekonomian.
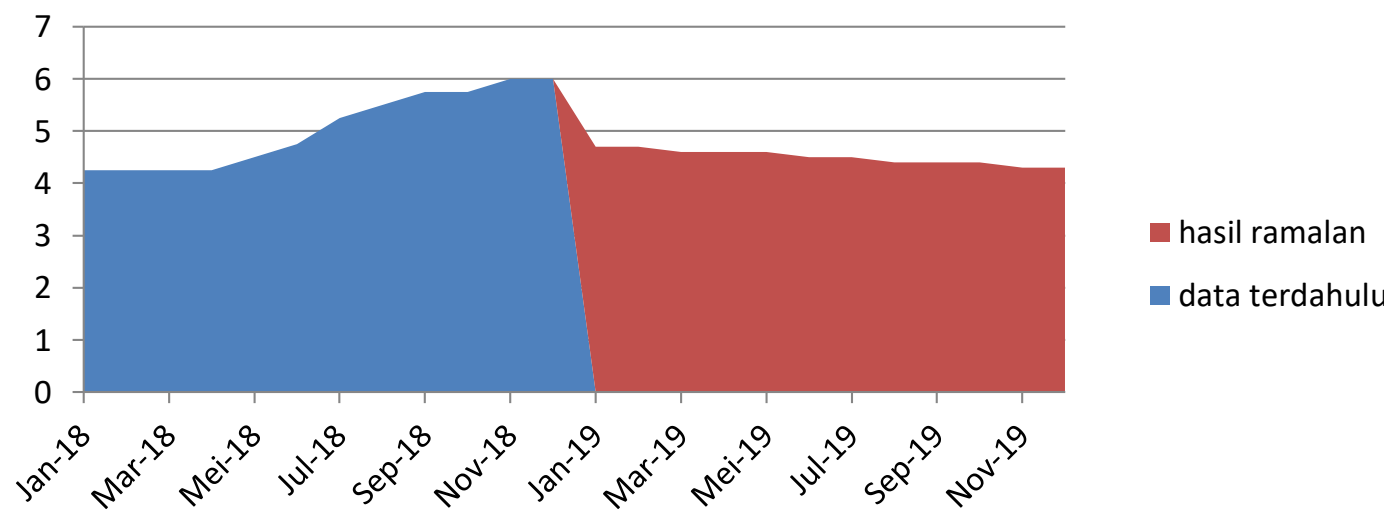

Sumber : Bank Indonesia, data diolah (2019).

Grafik 2. Trend suku bunga

Berdasarkan Grafik 2, angka suku bunga kebijakan bank sentral di Indonesia periode Januari - Desember 2019 relatif menurun disetiap bulannya. Pada Januari dan Februari 2019 nilai suku bunga standar diangka 4,7\% dan kembali menurun di tiga periode berikutnya yaitu Maret, April dan Mei 2019 sebesar 4,6\%. Nilai suku bunga relatif menurun sebesar 0,1\% pada beberapa periode sehingga di Desember 2019, nilai suku bunganya sebesar $4,3 \%$. 


\section{Analisis trend inflasi}

Kenaikan harga dari satu atau dua barang saja tidak disebut inflasi, kecuali bila kenaikan tersebut meluas kepada (atau mengakibatkan kenaikan) sebagian besar dari harga barang - barang lain (Boediono, 2014).

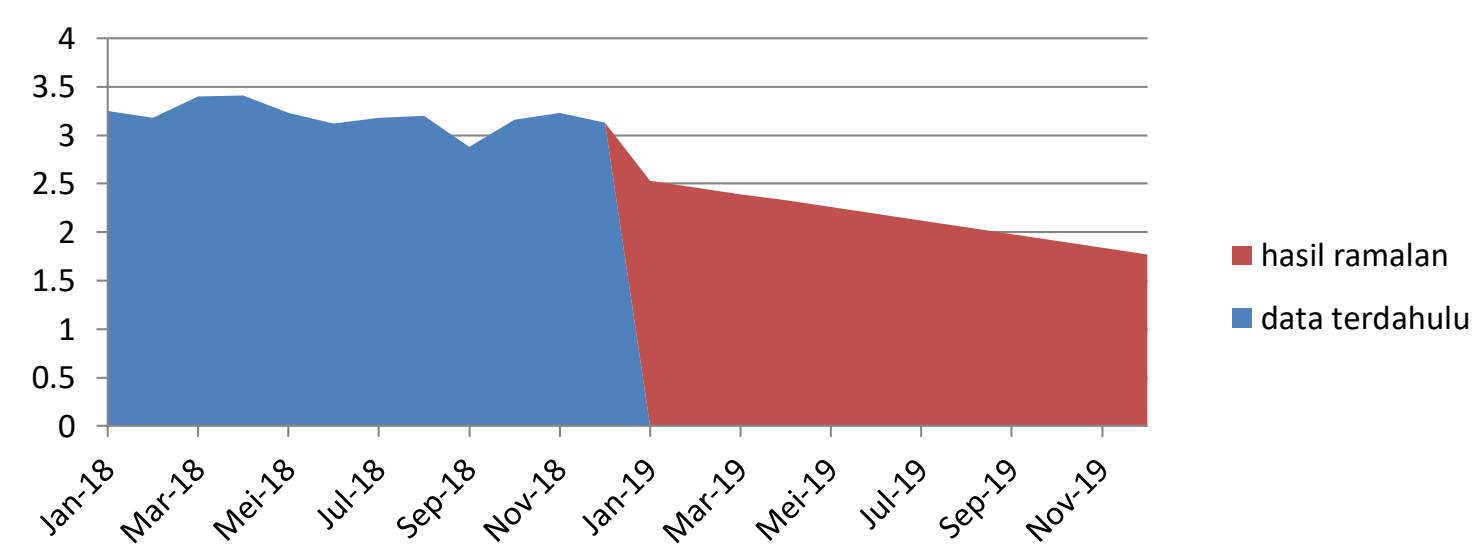

Sumber : Bank Indonesia, data diolah (2019).

Grafik 3. Trend inflasi

Berdasarkan Grafik 3, nilai inflasi di Indonesia disetiap periode nya mengalami penurunan sebesar 0,07\%. Pada Januari 2019 nilai inflasi mencapai 2,53\% dan mengalami penurunan di bulan selanjutnya sebesar 2,46\%. Sehingga diakhir tahun 2019 yitu pada bulan Desember nilai inflasi di Indonesia sebesar 1,77\%.

\section{Analisis trend jumlah uang beredar}

Menurut Sukirno (2000), uang yang beredar atau penawaran uang adalah jumlah uang yang tersedia dalam perekonomian dan dapat digunakan untuk membiayai transaksi - transaksi yang dilakukan dalam masyarakat.

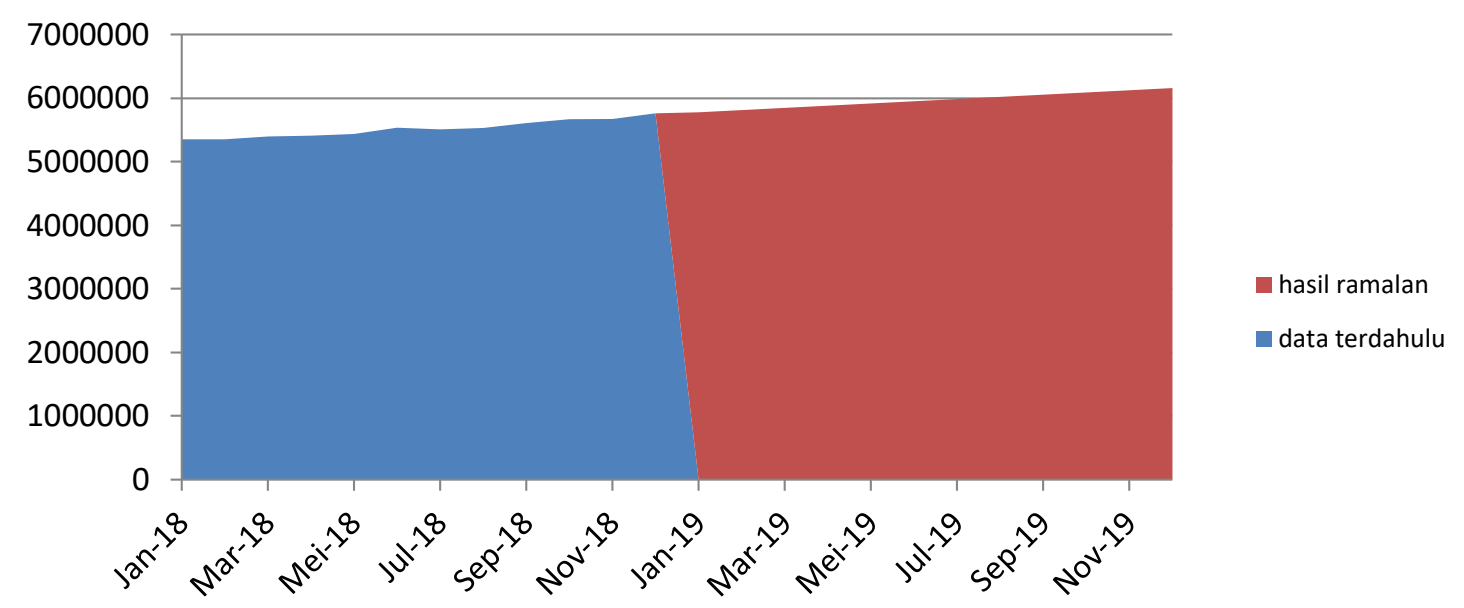

Sumber : Bank Indonesia, 2019 (diolah)

Grafik 4. Trend jumlah uang beredar

Peredaran uang M2 di Indonesia mengalami peningkatan disetiap bulannya sebesar Rp. 34.643. dapat dilihat tabel diatas, bulan Januari 2019 angka jumlah uang beredar sebesar Rp.5.776.376,23 dan mengalami kenaikan di bulan selanjutnya sebesar Rp. 5.811.019,13 ini membuktikan bahwa peredaran uang M2 di Indonesia engalami 
peningkatan secara terus - menerus, hingga diakhir periode pada Desember 2019 angka jumlah uang beredar mencapai Rp. 6.157.448,12.

\section{Analisis regresi model VAR}

\section{Uji stasioneritas data}

Hasil memperlihatkanuntuk variabel nilai tukar rupiah, suku bunga kebijakan bank sentral, inflasi dan jumlah uang beredar dalam penelitian stasioner pada tingkat $2^{\text {nd }}$ difference karena memiliki probabilita lebih kecil dari 0,05. Hal ini mengindikasikan bahwa dalam penelitian akan digunakan data terintegrasi pada derajat dua $\left(2^{\text {nd }}\right.$ difference).

\section{Uji optimal lag}

Pengujian panjang lag untuk mengetahui seberapa lama waktu yang dibutuhkan masing-masing variabel kaitannya dengan pengaruh variabel masa lalunya yaitu diperlukan pengujian panjang lag. Pada penelitian ini, penentuan optimum lag diuji melalui Akaike Information Criteria (AIC) yang paling rendah atau minimum (yang diberi tanda *).

Tabel 1. Uji optimal lag

\begin{tabular}{ccccccc}
\hline Lag & LogL & LR & FPE & AIC & SC & HQ \\
\hline 0 & -1745.649 & NA & $6.03 \mathrm{e}+16$ & 49.98998 & 50.11847 & 50.04102 \\
1 & -1375.016 & $688.3193^{*}$ & $2.40 \mathrm{e}+12^{*}$ & $39.85760^{*}$ & $40.50003^{*}$ & $4011278^{*}$ \\
2 & -1360.698 & 24.95495 & $2.53 \mathrm{e}+12$ & 39.90564 & 41.06201 & 40.36497 \\
\hline
\end{tabular}

Sumber : Data diolah (2019)

Berdasarkan hasil dapat dilihat bahwa nilai AIC untuk variabel kurs, suku bunga, inflasi dan jumlah uang beredar terdapat pada lag 1. Oleh karena itu, panjang lag optimal ini dapat digunakan dalam pengujian kausalitas.

\section{Uji stabilitas model VAR}

Uji stabilitas dalam penelitian ini menggunakan VAR Stability Condition Check melalui Roots Of Table. Syarat yang harus dipenuhi dalam uji ini adalah nilai modulus variabel harus < 1 (lebih kecil) dari 1. Tujuan menguji stabilitas VAR agar hasil estimasi pada model VAR yang tidak stabil akan menyebabkan analisis IRF tidak valid (Roshinta, 2014).Berdasarkan hasil menunjukkan bahwa nilai modulus yang paling besar kurang dari satu dan berada pada titik optimal dan model VAR sudah stabil.

\section{Uji kausalitas granger}

Uji kausalitas granger dilakukan untuk melihat apakah dua variabel memiliki hubungan timbal balik atau tidak. Dengan kata lain, apakah satu variabel memiliki hubungan sebab akibat dengan variabel lainnya secara signifikan.

Tabel 2 menjelaskan bahwa yang memiliki hubungan kausalitas adalah yang memiliki nilai probabilitas yang lebih kecil daripada alpha $0,005(<\alpha=0,05)$ sehingga $\mathrm{H}_{0}$ akan ditolak yang berarti suatu variabel akan mempengaruhi variabel lain. Dari hasil yang diperoleh yang mempunyai hubungan kausalitas adalah nilai tukar dan infasi, inflasi dan suku bunga kebijakan bank sentral, inflasi dan jumlah uang beredar.

Tabel 2. Uji kausalitas granger 


\begin{tabular}{lccc}
\hline Null Hypothesis & Obs & f-statistic & prob \\
\hline Suku bunga does not granger cause kurs & 70 & 2.97718 & 0.0579 \\
Kurs does not granger cause suku bunga & & 2.20507 & 0.1184 \\
Inflasi does not granger cause kurs & 70 & 0.29940 & 0.7423 \\
Kurs does not granger cause inflasi & & 4.13977 & 0.0203 \\
Jub does not granger cause kurs & 70 & 1.11446 & 0.3343 \\
Kurs does not granger cause jub & & 0.48656 & 0.6170 \\
Inflasi does not granger cause suku bunga & 70 & 4.66458 & 0.0128 \\
Suku bunga does not granger cause inflasi & & 0.40526 & 0.6685 \\
Jub does not granger cause suku bunga & 70 & 2.53970 & 0.0867 \\
Suku bunga does not granger cause jub & & 0.91936 & 0.4039 \\
Jub does not granger cause inflasi & 70 & 4.77212 & 0.0116 \\
Inflasi does not granger cause jub & & 0.76286 & 0.4705 \\
\hline
\end{tabular}

Sumber : Data diolah (2019)

\section{Uji kointegrasi}

Uji kointegrasi bertujuan untuk mengetahui apakah terjadi keseimbangan dalam jangka panjang, yaitu terdapat kesamaan pergerakan dan stabilitas hubungan antara variabel - variabel didalam penelitian. Berdasarkan hasil, diketahui bahwa nilai trace statistic dan maximumeigenvalue pada $\mathrm{r}=0$ lebih kecil dari critical value dengan tingkat signikansi 0,05\%. Dapat disimpulkan bahwa variabel Nilai Tukar, Suku Bunga Kebijakan Bank Sentral, Inflasi dan Jumlah Uang Beredar tidak memiliki hubungan /keseimbangan pergerakan dalam jangka panjang.

\section{Estimasi model var}

Penentuan model VAR dapat dilakukan jika tidak terjadi kointegrasi pada variablvariabel penelitian, jika terjadi kointegrasi diantara variabe penelitian maka estimasi dilakukan dengan model VECM. Sigmifikan atau tidaknya lag dari suatu variabel terhadap variabel lainnya dapat dilihat menggunakan nilai mutlak dari t-statistik (nilai yang ada dalam tanda kurung [..]).

Berdasarkan hasil, terdapat 8 variabel yang signifikan pada taraf 10\% ditambah 1 variabel error correction. Kedelapan variabel yang signifikan tersebut adalah Kurs pada lag 1, Suku Bunga pada lag 1, Suku bunga pada lag 2, Inflasi pada lag 1, Jumlah uang beredar pada lag 1, Jumlah uang beredar pada lag 2, dan pada error correction. Pada dugaan parameter error correction yang signifikan membuktikan bahwa adanya mekanisme penyesuaian dari jangka pendek ke jangka panjang.

\section{Analisis impulse response function (IRF)}

Respon variabel nilai tukar terhadap variabel suku bunga pada periode awal mendapat respon yang positif sebesar 0.02 persen.Periode kesepuluh inilah menjadi periode konvergen. Secara umum, respon nilai tukar terhadap suku bunga adalah positif sebagai mana terlihat dari respon kumulatif pada gambar.Respon variabel nilai tukar terhadap variabel inflasi menujukkan respon yg positif pada periode awal sebesar 0.10 persen. Periode knvergen terjadi pada periode keempat. Selanjutnya, respon nilai tukar terhadap inflasi di periode kelima sampai keperiode terakhir mengalami penurunan hingga mencapai angka negatif sebesar -0.075 persen. Secara umum dapat terlihat bahwa respon nilai tukar terhadap inflasi adalah positif dan signifikan.

Respon nilai tukar terhadap variabel jumlah uang beredar, dari periode awal hingga periode terakhir tidak mengalami yang namanya periode konvergen. Respon nilai tukar terhadap jumlah uang beredar menunjukkan respon yang positif, dapat dilihat dari grafik diatas di periode pertama sebesar 14.00 persen dan terus mengalami 
penurunan hingga periode terakhir sebesar 5.00 persen. Dan dapat disimpulkan bahwa respon nilai tukar terhadap jumlah uang beredar menghasilkan respon yang positif.

\section{Analisis forecast error variance decomposition(FEVD)}

Perubahan nilai tukar (Kurs) secara umum di dominasi oleh guncangan nilai tukar itu sendiri dengan komposisi varian sebesar 100 persen pada periode pertama dan terus mengalami penurunan pada periode berikutnya hingga menyentuh varian sebesar 41,98 persen pada periode terakhir atau periode kesepuluh. Variabel selanjutnya yang memberikan kontribusi pada perubahan nilai tukar adalah suku bunga kebijakan bank sentral. Kontribusi suku bunga kebijakan bank sentral menujukkan respon yang baik terhadap perubahan nilai tukar karena disetiap periode mengalami peningkatan yang cukup signifikan.

Variabel inflasi memberikan kontribusi yang sedikit pada perubahan nilai tukar di periode kedua sebesar 0.52 persen, tetapi signifikan di periode-periode berikutnya dan teru mengalami peningkatan hingga di periode terakhir sebesar 11.01 persen. Sama dengan hal nya inflasi, variabel jumlah uang beredar juga memberikan kontribusi yang kecil terhadap perubahan nilai tukar, dan terus mengalami peningkatan yang signifikan hingga di periode terakhir sebesar 11.3 persen.

\section{Pengujian secara simultan (Uji F)}

Uji F digunakan untuk menunjukkan apakah keseluruhan variabel independen berpengaruh terhadap variabel dependen dengan menggunakan Level of significance 5\%. Kriteria pengujiiannya apabila Prob. F hitung $<\propto$ berarti seluruh variabel independen berpengaruh secara signifikan terhadap variabel dependen dengan taraf signifikan tertentu.Berdasarkan hasil olahan data bahwa nilai Prob. F hitung $(0,000000)$ $<\propto(0.05)$. Jadi dapat disimpulkan bahwa variabel independen secara bersama-sama berpengaruh terhadap variabel dependen.

\section{Pengujian secara parsial (Uji t)}

Berdasarkan hasil olahan data nilai prob. Suku bunga kebijakan bank sentral dan jumlah uang beredar lebih kecil dari nilai $\alpha 5 \%(0,05)$ dan t-Statistik bernilai positif. Hal ini menunjukkan bahwa Suku bunga kebijakan bank sentral dan jumlah uang beredar berpengaruh positif dan signifikan terhadap nilai tukar rupiah, sedangkan nilai Prob. Inflasi besar dari nilai a 5\%(0,05). Hal ini menunjukkan bahwa inflasi tidak berpengaruh secara signifikan dan negatif terhadap nilai tukar rupiah.

\section{Koefesien determinasi $\left(\mathbf{R}^{2}\right)$}

Berdasarkan hasil perhitungan statistik diperoleh besarnya nilai koefesien determinan $\left(\mathrm{R}^{2}\right)$ adalah 0,939690 . Hal ini menunjukkan bahwa persentase pengaruh variabel independen keseluruhan (suku bunga kebijakan bank sentral, inflasi dan jumlah uang beredar) terhadap variabel independen (nilai tukar) adalah sebesar 93,97 persen. Artinya suku bunga kebijakan bank sentral, inflasi dan jumlah uang beredar memiliki persentase pengaruh terhadap nilai tukar sebesar 93,97 persen, sedangkan sisanya 6,03 persen dipengaruhi oleh variabel di luar model regresi yang diteliti.

\section{Uji multikolinieritas}

Uji Multikolinearitas dilakukan untuk menguji atau tidaknya hubungan linear yang sempurna atau pasti antara beberapa atau semua variabel yang menjelaskan model regresi. Jika koefisien koreasi antara masing-masing variabel bebas lebih kecil dari 10 , berarti model tersebut mampu menjelaskan dengan baik perilaku variabel dependen (Gujarati, 2003). Uji multikolineritas juga merupakan salah satu syarat dalam uji asumsi klasik dengan menggunkan uji VIF. 
Tabel 3. Uji multikoinieritas

\begin{tabular}{cccc}
\hline Variabel & Coefficient Variance & Uncentered VIF & Centered VIF \\
\hline C & 365031.5 & 229.0972 & NA \\
Suku bunga & 2103.922 & 52.73060 & 2.114034 \\
Inflasi & 1290.956 & 23.48688 & 2.817529 \\
JUB & $7.63 \mathrm{E}-09$ & 100.0143 & 2.494913 \\
\hline
\end{tabular}

Sumber : Data diolah (2019)

Berdasarkan hasil olahan data nilai Centered VIF kurang dari 10, maka dapat disimpulkan bahwa tidak terjadi multikolinieritas dan hal tersebut menunjukkan adanya hubungan linier yang sempurna diantara beberapa atau semua variabel independent dari model regresi.

\section{Uji heterokedasitas}

Pengujian ini untuk mengetahui apakah dalam regresi terjadi ketidaksamaan variance dari residual satu pengamatan ke pengamatan lain.

Tabel 4. Uji heterokedasitas

\begin{tabular}{llll}
\hline f-statistic & 1.660489 & Prob. F $(3,69)$ & 0.1837 \\
Obs *R-squared & 4.914476 & Prob. Chi-square & 0.1782 \\
Scaled explained & 5.245124 & Prob. Chi-square & 0.1547 \\
\hline
\end{tabular}

Sumber : Data diolah (2019)

Berdasarkan hasil olahan data di dapat bahwa nilai chi-square hitung sebesar 4,914476 yang dapat dilihat dari Obs*R-squared. Sementara dapat dilihat nilai Prob. Chi-Squared dari model ini ialah 0,1782 atau $17,82 \%$, yang menunjukan bahwa nilai tersebut lebih besar dari nilai kritis Chi-Squared $\left(\mathrm{x}^{2}\right)$ yaitu sebesar 0,05 atau $5 \%$. Maka dapat disimpulkan bahwa tidak memiliki sifat heterokedasitas.

\section{Uji autokorelasi}

Salah satu cara yang digunakan untuk melihat autokorelasi yaitu dilhat dari nilai probablita Chi square, jika lebih kecil dari alpha maka terdapat autokorelasi.

Tabel 5. Uji autokorelasi

\begin{tabular}{llll}
\hline F-statistic & 39.47824 & Prob. F(2.66) & 0.0000 \\
Obs*R-Squared & 39.21775 & Prob. Chi-squared & 0.0000 \\
\hline
\end{tabular}

Sumber : Data diolah (2019)

Berdasarkan hasil olahan data didapat bahwa model regresi tidak terjadi autokorelasi. Hal ini dapat dilihat dari nilai Prob.Chi-Square sebesar 0,0000 atau lebih kecil dari nilai $\propto=5 \%(0,05)$. Maka dapat disimpulkan bahwa terjadi hubungan lineardalam model yang digunakan.

\section{Uji normalitas}

Uji signifikansi pengaruh variabel independen terhadap variabel dependen melalui uji hanya akan valid jika residual yang didapatkan memiliki distribusi yang normal.Berdasarkan hasil olahan data diperoleh nilai probabilitas yakni sebesar 0,792479 atau sebesar $79,25 \%$ dan lebih besar dari nilai $\propto=5 \%$ maka dapat disimpulkan bahwa data terdistribusi dengan normal. 


\section{KESIMPULAN DAN SARAN}

\section{Kesimpulan}

Analisis trend pada nilai tukar rupiah selama periode Januari 2019 - Desember 2019 mengalami peningkatan dari periode sebelumnya, rata-rata perkembangan nilai tukar rupiah adalah Rp. 15.145 US\$. Perkembangan suku bunga kebijakan bank sentral Indonesia cenderung mengalami penurunan, rata-rata nya sebesar 4.5 persen. Perkembangan inflasi di Indonesia juga mengalami penurunan dari periode sebelumnya dengan rata-rata sebesar 2.15 persen. Untuk perkembangan jumlah uang beredar di Indonesa mengalami peningkatan yang signifikan yaitu dengan rata-rata sebesar $\mathrm{Rp}$. 5.966.912,17 millyar. Faktor-faktor yang mempengaruhi nilai tukar rupiah Indonesia berdasarkan hasil regresi berganda model VAR yaitu variabel suku bunga kebijakan bank sentral dan jumlah uang beredar. Sedangkan untuk variabel inflasi menunjukkan hubungan yang negatif terhadap nilai tukar rupiah.

\section{Saran}

Menjaga nilai tukar mata uang domestik terdepresiasi maka harus mengkaji lagi tentang segala kebijakan yang diterapkan serta dapat dengan segera untuk membenahi kondisi keuangan dalam negeri agar nilai tukar rupiah di tahun mendatang dapat terkendali. Diharapkan pemerintah dan lembaga - lembaga terkait khususnya Bank Indonesia selalu mengeluarkan kebijakan yang dapat menjaga stabilitas perekonomian demi menghindari fluktuasi nilai tukar. Adanya pengaruh pergerakan nilai tukar terhadap perekonomian mengharuskan terjadinya koordinasi kebijakan moneter untuk menciptakan ekonomi yang kuat dan seimbang, khususnya penetapan jumlah uang beredar, suku bunga dan inflasi.

\section{DAFTAR PUSTAKA}

Agustin, Grisvia. (2009). Analisis paritas daya beli pada kurs rupiah terhadap Dolar Amerika Serikat Periode September 1997 -Desember 2007 dengan Menggunakan Metode Error Correction Model. Jurnal IESP.1(1), 152.

Boediono. (2014). Ekonomi makro edisi ke empat.BPFE: Yogyakarta.

Fauji, Diah Ayu. (2016). Faktor-faktor yang mempengaruhi nilai tukar rupiah Periode 2013 Triwulan I 2015.Jurnal Ekonomi dan Bisnis. 2(10), 84-85

Gujarati, Damodar. (2003), Ekonometrika dasar, Terjemahan: Sumarno Zain. Erlangga: Jakarta.

Mankiw, Gregory. (2006). Makroekonomi edisi keenam. Erlangga. Jakarta.

Marsuki. (2005). Analisis sektor perbankan moneter dan keuangan Indonesia. Edisi pertama. Wacana Media: Jakarta.

Musyaffa, Arfidan Sabiq., dan Sulasmiyati, Sri. (2017). Pengaruh jumlah uang beredar inflasi dan suku bunga terhadap nilai tukar rupiah terhadap Dollar. Jurnal Administrasi Bisnis.50(4), 21-22.

Roshinta,dkk. (2014). Pengaruh tingkat inflasi, tingkat suku bunga sbi dan pertumbuhan ekonomi terhadap nilai tukar Rupiah Studi periode 2003 2012. Jurnal Administrasi Bisnis (JAB). 8(1), 36-37.

Sukirno, Sadono. (2006). Pengantar ilmu ekonomi makro. PT. Raja Grafindo Persada: Jakarta

Widarjono, Agus. (2009). Ekonometrika: pengantar dan aplikasinya. EdisiKeempat. UPP STIM YKPN: Yogyakarta

Yeniwati, (2014).Analisis perubahan kurs rupiah terhadap dollar. Jurnal Ekonomi dan Bisnis.2 (4), 1-14

Yudiarti,T; Emilia,E; \& Mustika,C. (2018).Pengaruh utang luar negeri, tingkat suku bunga dan neraca transaksi berjalan terhadap nilai tukar Rupiah terhadap Dolar Amerika Serikat, e-Jurnal Perdagangan Industri dan Moneter 6 (1), 14-22 